\title{
PENGARUH UKURAN PERUSAHAAN, KINERJA KEUANGAN, DAN KEPEMILIKAN INSTITUSIONAL TERHADAP PENGUNGKAPAN SOSIAL DAN LINGKUNGAN PERUSAHAAN (Studi Empiris pada Laporan Keberlanjutan Perusahaan BUMN tahun 2013-2017)
}

\author{
Gusti Ayu Wulandita Yuliawati ${ }^{1}$, Made Arie Wahyuni², \\ I Gede Agus Pertama Yudantara ${ }^{3}$
}

\author{
Jurusan Ekonomi dan Akuntansi, Fakultas Ekonomi, Universitas Pendidikan Ganesha \\ Singaraja, Indonesia
}

e-mail: ayu193621@gmail.com, wahyuni arie@yahoo.com, agus.yudantara@undiksha.ac.id

\begin{abstract}
Abstrak
Penelitian ini bertujuan untuk mengetahui pengaruh ukuran perusahaan, kinerja keuangan, dan kepemilikan institusional terhadap pengungkapan sosial dan lingkungan perusahaan BUMN yang listing di BEI tahun 2013-2017. Melakukan studi empiris pada laporan keberlanjutan perusahaan BUMN untuk mengetahui efektifitas pengungkapan sosial dan lingkungan dengan berpedoman pada Global Reporting Initiative G4 melalui tiga variabel dependen tersebut. Desain yang digunakan dalam penelitian ini adalah penelitian kuantitatif. Jumlah sampel adalah 10 perusahaan yang terpilih melalui teknik purposive samplingdengan total 50 sampel dari 5 tahun pengamatan. Metode analisis data yang digunakan yaitu analisis regresi berganda dan penyajian data dibantu dengan program Statistical Package for Social Science (SPSS) 24.0 for windows.

Hasil penelitian menunjukan bahwa ukuran perusahaan berpengaruh secara positif terhadap pengungkapan sosial dan lingkungan perusahaan, Kinerja Keuangan berpengaruh positif terhadap pengungkapan sosial dan lingkungan perusahaan, dan Kepemilikan Institusional berpengaruh positif terhadap pengungkapan sosial dan lingkungan perusahaan, serta ukuran perusahaan, kinerja keuangan dan kepemilikan institusional secara bersama - sama berpengaruh positif terhadap Pengungkapan Sosial dan Lingkungan Perusahaan BUMN yang terdaftar di Bursa Efek Indonesia.
\end{abstract}

Kata Kunci: Ukuran Peusahaan, Kinerja Keuangan, Kepemilikan Institusional, Pengungkapan Sosial dan Lingkungan

This research aimed at determining the effect of company size, financial performance, and institutional ownership on the social and environmental disclosures of the state-owned companies listed on the Indonesia Stock Exchange in 2013-2017. Conducting an empirical study on the sustainability reports of the state-owned companies to determine the effectiveness of social and environmental disclosures through the G4 Global Reporting Initiative guide using the three dependent variables. The design used in this research was quantitative research. The number of samples was 10 companies selected through purposive sampling technique with a total of 50 samples from 5 years of observations. The data analysis method used was multiple regression analysis and the data presentation was assisted by the Statistical Package for Social Science (SPSS) program 24.0 for Windows.

The results showed that the company size had a positive effect on the company social and environmental disclosure, the financial Performance had a positive effect on the company social and environmental disclosure, and the institutional ownership had a positive effect on the company social and environmental disclosures, and simultaneously had a positive effect on company social and environmental disclosures.

Keywords: Company Size, Financial Performance, Institutional Ownership, Social and Environmental Disclosures 


\section{Pendahuluan}

Keberadaan perusahaan dapat memberikan aspek positif dan negatif. Di satu sisi, perusahaan menyediakan barang dan jasa yang diperlukan oleh masyarakat, namun disisi lain tidak jarang masyarakat mendapatkan dampak buruk dari aktifitas bisnis perusahaan. Banyak kasus ketidakpuasan publik bermunculan baik yang berkaitan dengan pencemaran lingkungan, perlakuan tidak adil terhadap pekerja, dan lain sebagainya.

Dengan adanya dampak sosial dan lingkungan tersebut, banyak upaya yang dilakukan berbagai pihak yang ikut andil dalam pelaksanaan tanggungjawab sosial dan lingkungan. Pemerintah memberlakukan undang-undang terkait lingkungan hidup yaitu Undang-Undang Republik Indonesia No. 32 tahun 2009 tentang Perlindungan Dan Pengelolaan Lingkungan Hidup. Selain itu, Undang-Undang No. 40 tahun 2007 tentang Perseroan Terbatas menyatakan bahwa perusahaan yang melakukan kegiatan yang berkaitan dengan sumber daya alam wajib melakukan tanggung jawab sosial dan lingkungan.

Pengungkapan yang transparan kepada publik merupakan salah satu prinsip manajemen dalam menyediakan informasi yang berkaitan dengan rencana dan aktivitasnya kepada pihak yang berkepentingan kepada perusahaan. Dalam penelitian ini menggunakan laporan pertanggung jawaban sosial dan lingkungan yang terpisah dari laporan tahunan perusahaan. Berdasarkan peraturan Otoritas Jasa Keuangan No. 51/PJOK.03/2017 tentang keuangan berkelanjutan bagi Lembaga jasa Keuangan, Emiten, dan Perusahaan Publik menyusun laporan keberlanjutan. Laporan keberlanjutan tersebut memuat mengenai kinerja ekonomi, sosial, dan lingkungan dalam menjalankan bisnis berkelanjutan.

Laporan keberlanjutan diperlukan dalam menyampaikan kinerja sosial dan lingkungan karena pengungkapan sosial dan lingkungan dalam laporan tahunan sudah kurang efektif karena dapat digunakan sebagai alat untuk mengamankan kedudukannya, dan mengalihkan perhatian stakeholder dari monitoring aktifitas manajemen laba (Prior et al., 2008). Hal tersebut bisa terjadi karena tidak sempurnanya audit di dalam praktek ekonomi, sehingga manajer dapat memiliki insentif merekayasa income yang dilaporkan untuk memaksimalkan kepentingannya. Dengan mengadopsi asumsi dalam teori keagenan bahwa manajemen akan berperilaku oportunistik, maka manajemen dapat memberikan informasi yang lebih melalui pengungkapan tanggungjawab sosial dan lingkungan dalam laporan tahuan perusahaan untuk mengalihkan perhatian para pengguna laporan keuangan dari manajemen laba yang dilakukan. Maka dari itu, diperlukannya laporan terpisah mengenai sosial dan lingkungan seperti laporan keberlanjutan.

Laporan keberlanjutan memiliki minat yang tinggi dari negara-negara di kawasan Asia Tenggara khususnya dii Indonesia. Laporan keberlanjutan diterbitkan sesuai dengan pedoman Global Reporting Initiative (GRI) yang merupakan pedoman berstandar internasional yang memudahkan pemangku kepentingan dalam memilah informasi mengenai sosial dan lingkungan perusahaan khususnya perusahaan Badan Usaha Milik Negara (BUMN) yang sudah listing di Bursa Efek Indonesia (BEI).

Faktor-faktor yang mempengaruhi pengungkapan sosial dan lingkungan perusahaan diantaranya ukuran perusahaan, kinerja keuangan (dengan proksi ROA), dan kepemilikan institusional. Suatu perusahaan dengan tingkat profitabilitas yang tinggi akan melakukan pengungkapan yang lebih luas, pada umumnya perusahaan besar memiliki informasi yang lebih lengkap sehingga besar kemungkinan pengungkapan informasi pertanggungjawaban sosial pada perusahaan tersebut (Rahmawati, 2011). Dalam teori legitimasi, ukuran perusahaan memiliki hubungan dengan pengungkapan sosial dan lingkungan perusahaan. Umumnya perusahaan yang lebih besar melakukan aktivitas yang lebih banyak sehingga memiliki pengaruh yang lebih besar terhadap masyarakat. Dari penjelasan diatas memberikan pemahaman bahwa semakin besar ukuran perusahaan, maka pengungkapan sosial dan lingkungan perusahaan tersebut semakin besar. Sehingga hipotesis penelitiannya adalah sebagai berikut:

$\mathrm{H}_{1}$ : Ukuran perusahaan berpengaruh positif terhadap pengungkapan sosial dan lingkungan perusahaan.

Selain ukuran perusahaan, kinerja keuangan juga mempengaruhi pengungkapan sosial dan lingkungan suatu perusahaan. Kinerja keuangan dalan penelitian ini diwakili oleh 
salah satu rasio profitabilitas yaitu Return on Asset (ROA). Menurut Kasmir (2008) ROA adalah rasio yang menunjukan hasil atas jumlah aktiva yang digunakan dalam perusahaan. ROA yang tinggi akan memberikan kesempatan yang lebih kepada manajemen dalam mengungkapkan serta melakukan program tanggungj awab sosial dan lingkungan perusahaan. Sehingga dapat dijelaskan bahwa ROA merupakan kemampuan entitas dalam menghasilkan laba dari aktiva yang dimiliki demi meningkatkan nilai pemegang saham. Oleh karena itu, semakin tinggi ROA suatu perusahaan maka semakin besar pengungkapan informasi sosial dan lingkungannya (Putra, 2011). Dari penjelasan diatas, memberi pemahaman bahwa semakin besar ROA suatu perusahaan maka semakin tinggi pengungkapan sosial dan lingkungan suatu perusahaan. Sehingga peneliti berasumsi bahwa:

$\mathrm{H}_{2}$ : Kinerja keuangan berpengaruh positif terhadap pengungkapan sosial dan lingkungan perusahaan.

Menurut Arif (2006) dalam Nurkin (2009) perusahaan dengan kepemilikan institusional yang besar (lebih dari 5\%) mengindikasikan kemampuannya untuk memonitor manajemen, yang memberikan pemahaman bahwa dengan tingkat kepemilikan institusional yang semakin tinggi akan meningkatkan tingkat pengawasan terhadap manajemen. Salah satu aktivitas perusahaan yang dimonitor oleh pemilik saham institusi adalah pengungkapan tanggung jawab sosial dan lingkungan perusahaan. Dengan kepemilikan institusional memiliki inisiatif yang kuat untuk memantau praktik pengungkapan sosial dan lingkungan perusahaan. Dari penjelasan diatas memberikan pemahaman bahwa semakin besar kepemilikan institusional maka semakin tinggi pengungkapan sosial dan lingkungan suatu perusahaan. Sehingga hipotesis penelitiannya adalah sebagai berikut:

$\mathrm{H}_{3}$ : Kepemilikan institusional berpengaruh positif terhadap pengungkapan sosial dan lingkungan perusahaan.

Penelitian juga melakukan pengujian secara simultan untuk mengetahui pengaruh dari keseluruhan variabel terhadap pengungkapan sosial dan lingkungan perusahaan. Sehingga hipotesis penelitiannya adalah sebagai berikut:

$\mathrm{H}_{4}$ : Ukuran perusahaan, kinerja keuangan dan kepemilikan institusional terhadap pengungkapan sosial dan lingkungan peusahaan.

Penelitian mengenai ukuran perusahaan, kinerja keuangan, dan kepemilikan institusional terhadap pengungkapan sosial dan lingkungan perusahaan memiliki hasil yang beragam. Nurkin (2009) dengan variabel independen yang diteliti adalah corporate governance, dengan profitabilitas menyatakan bahwa kepemilikan institusional tidak berpengaruh signifikan terhadap pengungkapan tanggung jawab sosial perusahaan, sementara profitabilitas terbukti secara signifikan berpengaruh positif, sedangakan ukuran perusahaan sebagai variabel kontrol berpengaruh secara positif terhadap pengungkapan sosial dan lingkungan perusahaan. Sedangkan Sari, dkk (2017) dalam hasil penelitiannya menyatakan bahwa ROA dan ukuran perusahaan tidak berpengaruh secara signifikan terhadap pengungkapan corporate social responsibility (CSR).

Hasil yang tidak konsisten dari penelitian-penelitian sebelumnya antara ukuran perusahaan dan kinerja keuangan (dengan proksi ROA) dengan pengungkapan sosial dan lingkungan merupakan fenomena yang sangat menarik dan perlu dilakukan pengujian ulang. Sementara kepemilikan institusional terhadap pengungkapan sosial dan lingkungan belum banyak dilakukan. Sehingga, hasilnya belum bisa dikatakan konsisten pengaruh kepemilikan institusional terhadap pengungkapan sosial dan lingkungan.

Perbedaan hasil penelitian di atas membuat peneliti tertarik untuk melakukan penelitian dengan judul "pengaruh ukuran perusahaan, kinerja keuangan, kepemilikan institusional terhadap pengungkapan sosial dan lingkungan perusahaan (studi empiris pada laporan keberlanjutan perusahaan BUMN tahun 2015-2017).

\section{Metode}

Penelitian ini menggunakan rancangan penelitian kuantitatif yang akan dilakukan pada perusahaan BUMN yang terdaftar di Bursa Efek Indonesia (BEI) tahun 2013-2017. Penelitian ini akan dilakukan dengan mengakses situs resmi PT. Bursa Efek Indonesia (www.idx.com) 
dan situs masing-masing perusahaan. Populasi penelitian ini adalah perusahaan BUMN yang terdaftar di Bursa Efek Indonesia yaitu sebanyak 19 perusahaan. Dalam penelitian ini sampel diambil dengan meng-gunakan metode purposive sampling. Adapun sampel dalam penelitian ini sebanyak 10 perusahaan BUMN.

Berdasarkan data yang diperoleh dari situs resmi Bursa Efek Indonesia, data yang digunakan adalah laporan tahunan dan laporan keuangan perusahaan selama periode 20132017 adalah 10 perusahaan dalam satu tahun jadi total sampel yang diambil adalah sebanyak 50 selama 5 tahun periode penelitian 2013-2017. Sampel penelitian dilakukan dengan menggunakan metode Purposive Sampling. Kriteria yang digunakan dalam penelitian ini yaitu (1) Perusahan yang diteliti merupakan perusahaan BUMN. (2) Perusahaan BUMN terdaftar dalam Bursa Efek Indonesia (BEI). (3) Perusahaan BUMN yang diteliti melakukan pengungkapan laporan keberlanjutan sesuai dengan pedoman Global Reporting Initiative (GRI) secara berturut-turut dalam rentang tahun 2013-2017.(4) Perusahaan melakukan pengung-kapan laporan keuangan dan laporan tahunan dalam bentuk Rupiah.

Metode analisis data yang digunakan adalah dengan metode regresi berganda. Metode ini digunakan untuk mengetahui pengaruh antara ukuran perusahaan, kinerja keuangan yang diproksikan oleh ROA, serta kepemilikan institusional terhadap pengungkapan sosial dan lingkungan perusahaan melalui studi empiris pada laporan keberlanjutan perusahaan BUMN tahun 2013-2017. Sebelum dilakukannya analisis regresi linier berganda terlebih dahulu dilakukan uji asumsi klasik yang meliputi: (1) uji normalitas, (2) uji multikolinieritas, (3) uji heteros-kedastisitas, dan (4) uji autokorelasi. Kemudian dilakukan analisis regresi linier berganda dan uji hipotesis yang terdiri dari uji $\mathrm{t}$, uji $\mathrm{F}$ dan koefisien determinasi, dengan bantuan program Statistical Package for Social Science (SPSS) 24.0 for windows.

\section{Hasil Penelitian dan Pembahasan}

Uji Normalitas yang dilakukan dengan tujuan untuk menilai sebaran data pada sebuah kelompok data atau variabel, apakah sebaran data tersebut berdistribusi normal berguna untuk menentukan data yang telah dikumpulkan berdistribusi normal atau diambil dari populasi normal. Berdasarkan pengalaman empiris beberapa pakar statistik, data yang banyaknya lebih dari 30 angka ( $\mathrm{>}$ 30), maka sudah dapat diasumsikan berdistribusi normal. Uji multikolinearitas bertujuan untuk Uji multikolinearitas menunjukan diketahui bahwa nilai NIF fari masing-masing variabel bebas lebih kecil dari 10 dan nilai tolerance lebih dari 0,10 . Nilai korelasi di antara variabel bebas dapat dikatakan mempunyai kolerasi yang lemah. Dengan demikian dapat disimpulkan bahwa di antara variabel bebas tidak ada kolerasi atau tidak terjadi multikolinearitas pada modal regresi linier. Hasil uji heterokedastisitas menunjukan bahwa nilai signifikansi antara variabel bebas dengan absolute (ABS) lebih besar dar 0,05. Jadi, dapat disimpulkan bahwa model regresi yang digunakan tidak terdapat adanya gejala heterokedastisitas. Uji Autokorelasi bertujuan menguji apakah dalam model regresu linier ada korelasi antara kesalahan pengganggu pada periode $t$ dengan kesalahan pengganggu pada periode t-1 (sebelumnya). Jika nilai DurbinWatson berkisar antara nilai atas (du) maka diperkirakan tidak terjadi autokorelasi (Ghozali, 2009:93).

Selanjutnya pengujian hipotesis dalam penelitian ini menggunakan analisis regresi berganda yang dapat dilihat dalam tabel 1 . Berdasarkan perhitungan regresi linier berganda pada Tabel 4.7, maka didapat hasil persamaan regresi sebagai berikut.

$Y=\alpha+\beta_{1} X_{1}+\beta_{2} X_{2}+\beta_{3} X_{3}+\varepsilon(1)$

$Y=-123,794+0,245 X_{1}+0,566 X_{2}+0,212 X_{3}+\varepsilon(2)$ berikut.

Berdasarkan model regresi yang terbentuk, dapat diinterpretasikan hasil sebagai

Pertama, Konstanta $-123,794$ menunjukan jika variabel ukuran perusahaan $\left(\mathrm{X}_{1}\right)$, kinerja keuangan $\left(\mathrm{X}_{2}\right)$, dan kepemilikan institusional $\left(\mathrm{X}_{3}\right)$ bernilai konstan, maka variabel 
pengungkapan sosial dan lingkungan perusahaan $(Y)$ memiliki nilai sebesar -123,794.Kedua, Variabel ukuran perusahaan $\left(X_{1}\right)$ memiliki koefisien positif 0,245 . Nilai koefisien regresi yang positif menunjukkan bahwa ukuran perusahaan $\left(X_{1}\right)$ berpengaruh positif terhadap pengungkapan sosial dan lingkungan perusahaan $(Y)$. Hal ini menggambarkan bahwa setiap kenaikan 1 satuan ukuran perusahaan $\left(\mathrm{X}_{1}\right)$ dapat meningkatkan pengungkapan sosial dan lingkungan perusahaan $(Y)$ sebesar 0,245 dengan asumsi bahwa variabel independen yang lainnya tetap.Ketiga, Variabel kinerja keuangan $\left(X_{2}\right)$ memiliki koefisien positif 0,566 . Nilai koefisien regresi yang positif menunjukkan bahwa kinerja keuangan $\left(\mathrm{X}_{2}\right)$ berpengaruh positif terhadap pengungkapan sosiall dan lingkungan perusahaan $(\mathrm{Y})$. Hal inii menggambarkan bahwa setiap kenaikan 1 satuan kinerja keuangan $\left(X_{2}\right)$ dapat meningkatkan pengungkapan sosial dan lingkungan perusahaan $(\mathrm{Y})$ sebesar 0,566 dengan asumsi bahwa variabel independen yang lainnya tetap.

Tabel 1. Analisis Regeresi Berganda

\begin{tabular}{ccccccc}
\hline & Model & \multicolumn{2}{c}{ Unstandardized Coefficients } & $\begin{array}{c}\text { Standardized } \\
\text { Coefficients }\end{array}$ & $t$ & Sig. \\
\cline { 3 - 5 } & & $\mathrm{B}$ & Std. Error & Beta & & \\
\hline 1 & (Constant) & $-123,794$ & 33,052 & & $\mathbf{- 3 , 7 4 5}$ & 0,001 \\
& $\mathrm{X}_{1}$ & 3,168 & 1,170 & 0,245 & 2,706 & 0,010 \\
& $\mathrm{X}_{2}$ & 2,363 & 0,365 & 0,566 & 6,466 & 0,000 \\
& $\mathrm{X}_{3}$ & 0,648 & 0,267 & 0,212 & 2,423 & 0,019 \\
\hline
\end{tabular}

Keempat, Variabel kepemilikan institusional $\left(X_{3}\right)$ memiliki koefisien positif 0,212 . Nilai koefisien regresi yang positif menunjukkan bahwa kepemilikan institusional $\left(X_{3}\right)$ berpengaruh positif terhadap pengungkapan sosial dan lingkungan perusahaan (Y). Hal ini menggambarkan bahwa setiap kenaikan 1 satuan kepemilikan institusional $\left(X_{3}\right)$ dapat meningkatkan pengung-kapan sosial dan lingkungan perusahaan $(Y)$ sebesar 0,212 dengan asumsi bahwa variabel independen yang lainnya tetap.

Hasil pengujian hipotesis $\mathrm{H}_{1}$ mengenai pengaruh ukuran perusahaan terhadap pengungkapan sosial dan lingkungan perusahaan menunjukkan nilai koefisien regresi sebesar 0,245 dengan nilai signifikansi uji t sebesar 0,010 . Oleh karena itu, hipotesis $\mathrm{H}_{1}$ diterima. Hal ini menunjukkan bahwa ukuran perusahaan berpengaruh positif terhadap pengungkapan sosial dan lingkungan perusahaan. Jadi, dapat disimpulkan bahwa jika ukuran perusahaan semakin tinggi,maka pengungkapan sosial dan lingkungan perusahaan semakin tinggi. Sebaliknya, jika ukuran perusahaan keuangan semakin rendah,maka pengungkapan sosial dan lingkungan perusahaan semakin rendah.

Hasil penelitian ini adalah hasil penelitian yang dilakukan oleh Herlina (2016) menyatakan bahwa ukuran perusahaan berpengaruh positif terhadap kebijakan pengungkapan tanggungjawab sosial dan lingkungan dan penelitian yang dilakukan oleh Cahya (2010) memberikan hasil yang selaras bahwa ukuran perusahaan berpengaruh secara parsial terhadap CSR perbankan di Indonesia. Berdasarkan penelitian terdahulu, ada dukungan bahwa ukuran perusahaan berpengaruh positif terhadap pengungkapan sosial dan lingkungan perusahaan BUMN.

Hasil pengujian hipotesis $\mathrm{H}_{2}$ mengenai pengaruh kinerja keuangan terhadap pengungkapan sosial dan lingkungan perusahaan menunjukkan nilai koefisien regresi sebesar 0,566 dengan nilai signifikansi uji t sebesar 0,000 . Oleh karena itu, hipotesis $\mathrm{H}_{2}$ diterima. Hal ini menunjukkan bahwa kinerja keuangan berpengaruh positif terhadap pengungkapan sosial dan lingkungan perusahaan. Jadi, dapat disimpulkan bahwa jika kinerja keuangan semakin tinggi,maka pengungkapan sosial dan lingkungan perusahaan semakin tinggi. Sebaliknya, jika kinerja keuangan semakin rendah,maka pengungkapan sosial dan lingkungan perusahaan semakin rendah.

Hasil penelitian konsisten dengan hasil penelitian yang dilakukan oleh Suraenah (2011) memberikan hasil bahwa profitabilitas yang diwakili oleh Return On Asset (ROA) secara parsial berpengaruh terhadap pengungkapan tanggung jawab sosial perusahaan 
atau CSRD. Berdasarkan penelitian sebelumnya, ada dukungan bahwa kinerja keuangan yang diwakili oleh ReturnOn Asset (ROA) dapat berpengaruh positif terhadap pengungkapan sosial dan lingkungan perusahaan BUMN.

Hasil pengujian hipotesis $\mathrm{H}_{3}$ mengenai pengaruh kepemilikan institusionalterhadap pengungkapan sosial dan lingkungan perusahaan menunjukkan nilai koefisien regresi sebesar 0,212 dengan nilai signifikansi uji t sebesar 0,019. Oleh karena itu, hipotesis $\mathrm{H}_{3}$ diterima. Hal ini menunjukkan bahwa kepemilikan institusional berpengaruh positif terhadap pengungkapan sosial dan lingkungan perusahaan. Jadi, dapat disimpulkan bahwa jika kepemilikan institusional semakin tinggi,maka pengungkapan sosial dan lingkungan perusahaan semakin tinggi. Sebaliknya, jika kepemilikan institusional semakin rendah,maka pengungkapan sosial dan lingkungan perusahaan semakin rendah. Hasil penelitian ini sejalan dengan hasil penelitian yang dilakukan oleh Raverte (2008) menyatakan bahwa struktur kepemilikan terbukti berpengaruh terhadap tingkat pengungkapan CSR pada perusahaan yang terdaftar di Spanyol. Berdasarkan penelitian sebelumnya, ada dukungan bahwa kepemilikan institusional berpengaruh positif terhadap pengungkapan sosial dan lingkungan perusahaan BUMN.

Hasil pengujian hipotesis $\mathrm{H}_{4}$ mengenai pengaruh ukuran perusahaan, kinerja keuangan dan kepemilikan institusionalterhadap pengungkapan sosial dan lingkungan perusahaan menunjukkan nilai signifikansi uji $F$ sebesar 0,000 . Oleh karena itu, hipotesis $\mathrm{H}_{4}$ diterima. Hal ini menunjukkan bahwa ukuran perusahaan, kinerja keuangan dan kepemilikan institusional bersama-sama berpengaruh positif terhadap pengungkapan sosial dan lingkungan perusahaan. Jadi, dapat disimpulkan bahwa jika ukuran perusahaan, kinerja keuangan dan kepemilikan institusional semakin tinggi,makapengungkapan sosial dan lingkungan perusahaan semakin tinggi. Sebaliknya, jikaukuran perusahaan, kinerja keuangan dan kepemilikan institusional semakin rendah,maka pengungkapan sosial dan lingkungan perusahaan semakin rendah.

Berbagai penelitian yang terkait mempengaruhi pengungkapan sosial dan lingkungan perusahaan menunjukan keanekaragaman hasil. Penelitian yang dilakukan oleh Herlina (2016) mengenai faktor-faktor yang mempengaruhi kebijakan pengungkapan tanggung jawab sosial dan lingkungan perusahaan memberikan hasil bahwa faktor leverage berpengaruh negatif terhadap pengungkapan tanggung jawab sosial dan lingkungan karena perusahaan yang memiliki leverage yang tinggi akan mengurangi pengungkapan yang dibuatnya untuk mengurangi sorotan dari Bondholder. Penelitian tersebut mengungkapkan pula bahwa profitabilitas berpengaruh negatif terhadap pengungkapan tanggung jawab sosial dan lingkungan karena semakin rendah profitabilitas maka semakin besar pengungkapan yang dilakukan oleh perusahaan. Begitu juga ukuran dewan komisaris, kepemilikan manajerial dan umur perusahaan tidak berpengaruh secara parsial terhadap penggungkapan tanggung jawab sosial dan lingkungan perusahaan, sedangkan ukuran perusahaan berpengaruh positif terhadap pengungkapan tanggung jawab sosial dan lingkungan. Berdasarkan penelitian terdahulu, ada dukungan bahwa ukuran perusahaan, kinerja keuangan diwakili oleh ROA, dan kepemilikan institusional dapat secara bersamasama berpengaruh positif terhadap pengungkapan sosial dan lingkungan perusahaan BUMN.

\section{Simpulan dan Saran}

Berdasarkan hasil penelitian, peneliti menyimpulkan bahwa ukuran perusahaan, kinerja keuangan, kepemilikan institusional berpengaruh positif terhadap pengungkapan sosial dan lingkungan perusahaan bersama-sama berpengaruh positif terhadap pengungkapan sosial dan lingkungan perusahaan. Hal ini berarti bahwa ukuran perusahaan memiliki hubungan dengan pengungkapan sosial dan lingkungan perusahaan karena ada inisiasi dari secara institusional untuk mewujudkan hal tersebut. Selain itu perusahaan melaksanakan melaporkan pengungkapan sosial dan lingkungan karena ingin menunjukkan bahwa perusahaan memiliki kemampuan entitas dalam menghasilkan laba dari aktiva yang dimiliki sehingga dapat meningkatkan nilai perusahaan di pemegang saham.

Peneliti menyarakankan bagi pembuat kebijakan pada perusahaan BUMN yang 
terdaftar di Bursa Efek Indonesia disarankan untuk melakukan review dan pembahasan mengenai standar pengukuran dan pengungkapan sosial dan lingkungan perusahaan agar investor dapat melakukan analisis yang tepat dalam menentukan nilai dan prospek perusahaan. Pada peneltian ini perusahaan-perusahaan belum maksimal melakukan pengungkapan sosial dan lingkungan perusahaan dengan rata-rata $29,01 \%$, maka sangat perlu ditetapkan standar yang baik agar pengungkapan sosial dan lingkungan perusahaan lebih komprehensif dan terstruktur.

Peneliti selanjutnya disarankan untuk memperluas populasi penelitian, yaitu dengan menambah jumlah sektor perusahaan tidak hanya yang ada pada perusahaan BUMN, sehingga diperoleh hasil penelitian yang tingkat generalisasinya lebih tinggi. Penelitian ini menggunakan periode penelitian yang relatif pendek yaitu dari tahun 2013 sampai dengan 2017. Penelitian selanjutnya disarankan untuk memperpanjang periode penelitian. Hal ini disebabkan karena waktu penelitian yang lebih panjang dapat memberikan data pengamatan yang lebih sehingga hasil penelitian memberikan generalisasi yang baik.

Berdasarkan hasil perhitungan koefisien determinasi sebesar 0,801. Hal ini menunjukkan bahwa $80,1 \%$ variabel pengungkapan sosial dan lingkungan perusahaandipengaruhi oleh variabell ukuran perusahaan, kinerja keuangan, dan kepemilikan institusional, sedangkan 19,9\% dipengaruhi oleh faktor lain. Dengan demikian disarankan bagi penelitii selanjutnya dapat menggunakan variabel lain yang mempengaruhi pengungkapan sosial dan lingkungan perusahaan.

\section{Daftar Pustaka}

Cahya, Bramantya Adhi. 2010. Analisis Pengaruh Kinerja Keuangan terhadap Tanggung Jawab Sosial Perusahaan (Corporate Social Responsibility). Skripsi. Universitas Diponegoro; Semarang

GRI. (2013). GRI Social and environmental Sector Disclosures. Amsterdam: Global Reporting Initiative.

Ghozali, Imam. 2011. Aplikasi Analisis Multivariate Dengan Program SPSS. Semarang: Badan Penerbit Universitas Diponegoro

Ghozali, I dan A. Chariri. 2007. Teori Akuntansi, Semarang: BG UNDIP

Ghozali, Imam dan Anis Chariri. 2007. Teori Akuntansi. Semarang : Badan Penerbit Universitas Diponegoro.

Harlina, 2016. Faktor-faktor yang mempengaruhi Kebijakan Pengungkapan Sosial dan Lingkungan pada Perusahaan yang terdaftar di Bursa Efek Indonesia. Baabu Al-IImmi Vol. 1 No. 2 Oktober 2016. STIE Musi Rawas.

Kasmir, 2008. Bank dan Lembaga Keuangan Lainnya. Edisi Revisi. Jakarta: PT Rajagrafindo Persada.

Ikatan Akuntansi Indonesia. 2007. Standar Akuntansi Keuangan. Salemba Empat : Jakarta

Nurkhin, Ahmad. 2009. Corporate Governance dan Profitabilitas; Pengaruhnya Terhadap Pengungkapan Tanggung Jawab Sosial Perusahaan (studi empiris pada perusahaan yang tercatat di bursa efek Indonesia). Tesis. Program Pascasarjana Universitas Diponegoro: Semarang.

Undang-undang Republik Indonesia No. 32 Tahun 2009 tentang Perlindungan dan pengelolaan lingkungan hidup, 2003. Jakarta

Undang-undang Republik Indonesia No. 40 Pasal 94 tahun 2007 tentang Perseroan Terbatas, 2007. Jakarta

Peraturan Otoritoritas Jasa Keuangan No.51/PJOK.03/2017 tentang Keuangan Berkelanjutan bagi lembaga jasa keuangan, emiten, dan perusahaan publik, 2017. Jakarta 
Putra, Tri Mahardika,. 2017. Pengaruh ukuran perusahaan, kepemilikan manajerial dan kinerja keuangan terhadap corporate environmental disclosure laporan tahunan perusahaan di indeks SRI Kehati periode 2012 - 2015. Jurnal Akuntansi Vol.3 Issue 4 (2017).

Prior, Diego. Surroca, Jordi and Tribo, Josep A. 2008. Are Socially Responsible Managers Really Ethical? Exploring the Relationship between Earnings Management and Corporate Social Responsibility. Corporate Governance : An international Review 16 (3) : 160-177.

Sari, Tri suci Indah. 2017. Pengaruh Kinerja Keuangan, Ukuran Perusahaan, Dan Kinerja Lingkungan Terhadap Pengungkapan Corporate Social Responsibility(Studi empiris pada perusahaan non -keuangan yang terdaftar di Bursa Efek Indonesia (BEI) yang telah mengikuti program penilaian peringkat kinerja perusahaan dalam pengelolaan lingkungan hidup (proper) tahun 2014-2016). SNAB Universitas Widyatama. Bandung

Rahmawati, Desie. 2011. Pengaruh struktur kepemilikan, ukuran perusahaan, perusahaan BUMN dan non BUMN terhadap luas pengungkapan tanggung jawab sosial (CSR Disclosurel) pada perusahaan di BEI tahun 2009. Skripsi. Universitas Diponegoro: Semarang.

Reverte, Carmelo. 2008, "Determinants of Corporate Social Responsibility Disclosure Ratings by Spanish Listed Firms". Journal of Business Ethics. http://www.springer.com. Diakses tanggal 30 Januari 2019.

Sugiyono, 2007. Metodelogi Penelitian Bisnis. Bandung : Alfabeta

Suraenah, 2011. Analisis Pengaruh Ukuran perusahaan, Profitabilitas, dan Leverage terhadap pengungkapan tanggung jawab sosial perusahaan (corporate social responsibility disclosure). Jurnal akuntansi. Universitas Gunadarma

www.idx.com diakses pada tanggal 7 Januari 2019 